\title{
Factors Influencing the Choice of Marketing Outlets among Small-Scale Pineapple Farmers in Kericho County, Kenya
}

\author{
Sigei K. Geoffrey (Correspondence Author) \\ Department of Agricultural Economics and Agribusiness Management \\ Egerton University, Kenya \\ E-mail: gsigei@ymail.com \\ Bett, K. Hillary \\ Department of Agricultural Economics and Agribusiness Management \\ Egerton University, Kenya \\ Kiprop, K. Jonah \\ Department of Agricultural Economics and Agribusiness Management \\ Egerton University, Kenya \\ Odipo, O. Timothy \\ Department of Agricultural Economics and Agribusiness Management \\ Egerton University, Kenya
}

Received: March 28, 2015

Accepted: July 2, 2015

Published: August 29, 2015

doi:10.5296/ijrd.v2i2.6237

URL: http://dx.doi.org/10.5296/ijrd.v2i2.6237

\begin{abstract}
Markets act as pivotal point in the agricultural transformation process. Access to market plays crucial role in exploiting the marketing opportunities for the pineapple farmers. In the study area, the strategies to unlock the market access among pineapple farmers are wanting and these have resulted to limited marketing outlets. This study therefore seeks to determine the factors influencing the choice of pineapple marketing outlets in Bureti district. The cross-sectional data were collected from a sample of 100 small-scale pineapple farmers. Data was analyzed using descriptive and Multinomial Logit model. The results showed that gender, group marketing, pineapple produce, price information, marketing under contract and vehicle ownership significantly influenced the choice of pineapple marketing outlets. The study has
\end{abstract}


potential policy implication of improving the pineapple marketing performance and the welfare of the farmer.

Keywords: Choice, Marketing outlets, Multinomial Logit model

\section{Introduction}

Smallholder agriculture remains the major engine of rural growth and livelihood improvement for any pathway that can lift large number of the rural poor out of poverty (Hazell, 2005). Barrett (2009) argued that the smallholder farmers who engaged in subsistence and semi-subsistence agriculture have low marketable surplus (low return) causing them to be in low equilibrium poverty trap. A leap that smallholder farmers need to make to reduce poverty and hunger is to transform from the low marketability semi-subsistence farming to high level market-oriented farming.

Market-oriented production has achieved welfare gain through specialization, comparative advantage, economies of scale, regular interaction and exchange of ideas (Barett, 2008). The success for this agricultural transformation has been accomplished though horticultural production. World Bank (2009) found horticulture industry to be the fastest growing agricultural sub-Sector in Kenya with contribution of more than $10 \%$ of the total agricultural production. Minot and Ngigi (2003) described horticulture to be of higher returns than most of the cash crops and are suitable for production on the currently declining farm sizes.

Market access has been identified as one of the critical factor influencing the performance of smallholders' agricultural in developing countries, and in particular, least developed countries (Barrett, 2008). Enhancing returns from agricultural production through improved access to market can therefore be vital element for enhancing agriculture-based economic growth and increasing rural income.

Although market are essential in the process of agricultural commercialization as many people argued, transaction costs and other causes of market imperfections could limit the participation of farm households in different markets. In order to withstand these market pressures, the farmers are required to transform the agricultural markets to vertical coordinated structure (Reardon and Barrett, 2000). Lack of information among the farmers can create inefficiencies and welfare losses for participants and potential participants (DFID, 2005). Therefore, in order to maintain their livelihood strategies and to reduce their vulnerability in the face of social, economic, and environmental challenges, the disadvantaged populations are required to enhance access to market information (Scott, 2007). The potential benefits of higher produce prices and lower input prices due to commercialization are effectively transmitted to poor households when market access is guaranteed (IFAD, 2001).

\section{Literature Review}

\subsection{Factors Influencing the Choice of Marketing Outlets}

Choice for the marketing outlet is the farmers' decision on where to or not to sell their farm produces. The choice of market outlet is determined by the price the farmers receive from the 
sale of producers. The farmer is likely to choose the one which gives higher benefits. In addition, the investigation of determinants of market outlet for mango producers in Costa Rica (Zuniga-Aria \& Ruben, 2007), showed four major factors in their analytical framework. The first factor was related to the farm household (including farmer's experience, an outlet which is profitable. Attitude toward risk positively and negatively influences the choice attitude toward risk); the second factor dealt with production system (farm size and production scale); the third determinant was price attributes; and the last was market context (having or not a written contract, geographical location and distance to urban market).

Farmer's experience, especially for marketing has influenced the farmer to choose the market of marketing outlet. Those who are risk taker are willing to transport their farm produces to distant places while risk averse, always resort to sell at farm-gate. Montshwe (2006) stated that the farm gate sale tends to reduce farmers' revenue since the prices are relatively low. Farm size is a proxy to production scale. When the land size is large the production scale is also large and vice versa. Large production scale positively influences the farmer to sell their produce at market place mainly because of economies of scale which lower transaction cost. Price attitude has an influence on the choice of marketing outlet. A higher price provides an incentive to the selling point. When the farm-gate or the market place price is higher, the farmers tend to sell at that point. Contract arrangement has an influence on the choice of marketing outlet. Contract arrangement guarantees the farmers a ready market. The farmers tend to choose the outlets that have a ready market either farm gate or market place. In most cases, the farmer chooses farm gate because it incurs no transaction cost. Distance to market place negatively influences the choice of marketing outlet. In an early study on infrastructure and market access in Madagascar, Minot (1999) showed that the choice of marketing outlet among trader is negatively related to the distance to the market site. Therefore, farmers tend to sell their outputs at farm gate because there is no transaction cost to be incurred.

\section{Methodology}

\subsection{The Study Area}

Bureti district is one of the districts in Kericho County. The district is located in $0.5^{0} \mathrm{~S}$ and $35.25^{0} \mathrm{E}$. The district occupies a total area of $955 \mathrm{~km}^{2}$. Economic activities in the district include: tea growing and processing; dairy farming; and commercial businesses. Other agricultural products include pineapple, maize, beans, potatoes, vegetables, and coffee.

\subsection{Sampling Techniques}

Multi-stage sampling procedure was used in the selection of representative sample. The first step involved purposive selection of two divisions among the three divisions and then five locations in Bureti district. The areas were selected purposively based on quantities and the numbers of smallholder pineapple farmers. Finally, 30 farmers in each location were selected randomly using simple random sampling to give a total sample of 150 farmers. Approximately 100 out of 150 respondents emerged to be market participants while the rest were non-market participants. The market participants were ultimately interviewed on the 
choice of marketing outlets. Primary data was collected through the administration of semistructured questionnaires.

STATA version 12 was used to process the data. To analyze data, descriptive statistics were used together with Multinomial Logit model. Descriptive statistics employed statistical tools such as mean and percentage to describe the marketing characteristics in relation to the choice of marketing outlets. The Multinomial Logit model was used because it permits the analysis of decisions across more than two categories in the dependent variables. In order to make rational decision, every farmer aim to maximize utility relative to his choices. It is assumed that given farmer $i$ in making a decision considering exclusive alternatives that constitute the choice set $I^{i}$ of pineapple marketing outlets, the choice set may differ according to the decision maker. The farmer $\breve{y} i$ assigns each alternative $j$ in his choice set of perceived utility $U_{j}^{i}$ and selects the marketing outlet that maximizes his utility. The utility assigned to each choice alternative depends on a number of measurable attributes of the alternative itself and the farmer who is the decision maker.

$$
U_{j}^{i}=U^{i} X_{j}^{i}
$$

where, $\mathrm{U}^{\mathrm{i}}$ is the perceived utility and $\mathrm{X}_{\mathrm{j}}^{\mathrm{i}}$ is a vector of attributes relative to alternative $j$ and to decision maker $i$, utility is not known with certainty and it must be represented in general by a random variable. Probability that the farmer will select alternative $j$ conditional of his choice set $I^{i}$ will be given by:

$$
P^{i}\left(j / I^{i}\right)=P^{i}\left(U_{j}^{i}>U_{k}^{i}\right), \forall k \neq j, k \in I^{i}
$$

The perceived utility $U_{j}^{i}$ can be expressed as sum of two terms: a systematic utility and a random residual. Systematic utility $V_{j}^{i}$ represents mean of all farmers having the same choice context as decision maker $i . \varepsilon_{j}^{i}$ captures the combined effects of the various factors that introduce uncertainty in choice modeling, it is expressed as:

$$
U_{j}^{i}=V_{j}^{i}+\varepsilon_{j}^{i} \forall j \in I^{i}
$$

With $V_{j}^{i}=E\left(U_{j}^{i}\right)$, then $E\left(V_{j}^{i}\right)=V_{j}^{i}, \operatorname{var}\left(V_{j}^{i}\right)=0$ and $E\left(\varepsilon_{j}^{i}\right)=0, \operatorname{var}\left(U_{j}^{i}\right)=\sigma_{i j}^{2}$ and this yields,

$$
P^{i}\left(j / I^{i}\right)=\operatorname{Pr} o b\left({ }^{i} V_{j}^{i}-V_{k}^{i}>\varepsilon_{k}^{i}-\varepsilon_{j}^{i}\right) \forall k \neq j k \in I^{i}
$$

Where $P^{i}$ is the choice probability. Equation 4 gives the probability of farmers selecting alternative $j$ and it suggests that the choice of a given alternative depends on the systematic utilities of all competing alternatives and on the law of joint probability of random residuals $\varepsilon_{j}$.

Therefore, the farmer is likely to choose the option that gives a higher utility among the alternatives. The choice of a given marketing outlet is discrete because it is chosen among 
other alternative outlet. Let $P_{i j}$ represents the probability of a choice of any given marketing outlet by pineapple farmers, then equation representing this will be:

$$
\mathrm{P}_{\mathrm{ij}}=\beta_{0}+\beta_{1} \mathrm{X}_{1}+\beta_{2} \mathrm{X}_{2}+\beta_{3} \mathrm{X}_{3}+\ldots+\beta_{\mathrm{k}} \mathrm{X}_{\mathrm{k}}+\varepsilon
$$

Where $i$ takes values $(1,2,3)$, each representing choice of marketing outlet (farm gate $=1$, local market $=2$, urban market $=3$ ). $X_{1}$ are factors affecting choice of a marketing outlet, $\beta$ are parameters to be estimated and $\varepsilon$ is randomized error. With $j$ alternative choices, probability of choosing outlet $j$ is given by:

$$
\operatorname{prob}\left(Y_{i}=j\right)=e_{z j} / \sum_{k-o}^{j} e_{z k}
$$

Where $\mathrm{z}_{j}$ is choice and $z_{k}$ is alternative choice that could be chosen (Greene, 2000). The model estimates are used to determine the probability of choice of a market outlet given $j$ factors that affect the choice $X_{i}$. With a number of alternative choices log odds ratio is computed as:

$$
\ln \left(\mathrm{P}_{\mathrm{ij}} / \mathrm{P}_{\mathrm{ik}}\right)=\alpha+\beta_{1} \mathrm{X}_{1}+\beta_{2} \mathrm{X}_{2}+\ldots+\beta_{\mathrm{n}} \mathrm{X}_{\mathrm{n}}+\mathrm{e}_{\mathrm{i}}
$$

$\mathrm{P}_{\mathrm{ij}}$ and $\mathrm{P}_{\mathrm{ik}}$ are probabilities that a farmer will choose a given outlet and alternative outlet respectively. $\ln \left(\mathrm{P}_{\mathrm{ij}} / \mathrm{P}_{\mathrm{ik}}\right)$ is a natural $\log$ of probability of choice $j$ relative to probability choice $k, \alpha$ is a constant, $\beta$ is a matrix of parameters that reflect the impact of changes in $X$ on probability of choosing a given outlet, e is the error term that is independent and normally distributed with a mean zero. The parameter estimates of the Multinomial Logit model provide only the direction of the effect of the independent variable on the dependent (response) variable but do not represent either the actual magnitude of change nor probabilities. The marginal effects or marginal probabilities are functions of the probability itself and measure the expected change in the probability of a particular choice being made with respect to unit change in an independent variable from mean (Green, 2000). Marginal effects of the attributes on choice are determined by getting the differential of probability of a choice and it is given by:

$$
(\delta)=\partial p_{i} / \partial X_{i}=P_{i}\left(\beta-\sum_{k-o}^{j} P_{k} \beta_{k}\right)=P_{i}\left(\beta_{j}-\beta\right)
$$

Multinomial Logit model is given below:

$$
\mathrm{P}_{\mathrm{ij}}=\beta_{0}+\beta_{1} \mathrm{X}_{1}+\beta_{2} \mathrm{X}_{2}+\ldots \ldots+\beta_{2} \mathrm{X}_{2}+\varepsilon_{i}
$$

Choice of market outlet $\left(\mathrm{P}_{\mathrm{ij}}\right)=\beta_{0}+\beta_{19 g e+} \beta_{2 g n d}+\beta_{3} E d u c+\beta_{4}$ PineOutcm + $\beta_{5}$ VehOwn $+\beta_{6}$ MktGrp $+\beta_{7}$ PricInfr $+\beta_{8}$ Contr $+\beta 9$ MktExpr $+\varepsilon i$

Table 1. Variables used in the multinomial logit model

\begin{tabular}{llll}
\hline Variable & Description & Measurement & Expected sign \\
\hline Age & Age of the household head & Years & + \\
Gnd & Gender of the household head & $1=$ Male, $0=$ Female & \pm \\
Educ & $\begin{array}{l}\text { Number of formal education } \\
\text { of the household head }\end{array}$ & Years & +
\end{tabular}


PineOutcm Amount of pineapple produce

VehOwn Vehicle ownership

MktGrp Marketing in groups

MktExpr

Marketing experience

Kilograms

$+$

PrInfr

Price information

Contr

Contract Arrangement

$1=$ Yes, $0=$ No

$\pm$

$1=$ Yes, $0=$ No

$\pm$

Years

$1=$ Yes, $0=$ No

$+$

$1=$ Yes, $0=$ No

$\pm$

$\pm$

\section{Results and Discussion}

\subsection{Market Characteristics in Relation to Marketing Outlets}

Table 2 and 3 presents continuous and categorical market characteristics in relation to marketing outlets.

Table 2. Continuous marketing characteristics in relation to marketing outlets

\begin{tabular}{llll}
\hline Variable & Mean & & \\
& Farm gate & Local market & Urban market \\
\hline Age & 48.76 & 44.76 & 38.29 \\
Education level (yrs) & 7.21 & 8.97 & 11.62 \\
\hline
\end{tabular}

Table 3. Categorical marketing characteristics in relation to marketing outlets

\begin{tabular}{lcccc}
\hline Variable & & \multicolumn{3}{c}{ Percentages } \\
& & Farm-gate & Local market & Urban market \\
\hline Gender & Male & 48 & 82 & 88 \\
Vehicle ownership & Female & 52 & 18 & 12 \\
& Yes & 21 & 44 & 96 \\
Price information & No & 79 & 56 & 4 \\
& Yes & 36 & 65 & 75 \\
Group marketing & No & 64 & 35 & 25 \\
& Yes & 7 & 35 & 71 \\
Contract marketing & No & 93 & 65 & 29 \\
& Yes & 64 & 53 & 17 \\
& No & 36 & 47 & 83 \\
\hline
\end{tabular}

The results in Table 2 indicate that the mean age of the market participants who used the farm-gate, local market and urban market as marketing outlet had 48.76 years, 44.76 years and 38.29 years, respectively. This implied that those who sold their produce at farm-gate were slightly younger than those who sold at local and urban market. This can be expounded by the fact that younger people tend to market their produce to a far distance places like urban markets because they are energetic and risk takers. In terms of education level, the result indicates that the average education level of the market participants who used the farm-gate, local market and urban market as marketing outlet had 7.21 years, 8.97 years and 
11.62 years, respectively. It is evident that the market participants who sold at urban market had higher level of education than those who sold at farm-gate and local market. With enhanced education, market participant has ability to perceive, interpret and assimilate marketing information that can lead to informed choice of markets with high level of returns like urban market.

The results in Table 3 indicate that $48 \%, 82 \%$ and $88 \%$ of the male headed households, used farm gate, local market and urban market, respectively as a choice of marketing outlets. On the other hand, $52 \%, 18 \%$ and $12 \%$ of the female headed households used farm-gate, local market and urban market, respectively as the choice of marketing outlets. This showed that the male headed households who used local and urban markets as the choice of marketing outlets were more than their counterparts. This implies that the male headed households are likely to be resource endowed hence they are capable of marketing their outputs at local and urban market. On the vehicle ownership, the results indicate that $21 \%, 44 \%$ and $96 \%$ of market participants used farm gate, local market and urban market, respectively as the choice of marketing outlets. This indicated that the majority of those who sold at urban market owned vehicles. In essence, vehicle ownership plays a fundamental role of providing the mean of transports to the market. In terms of price information, the results reveal that $36 \%$, $65 \%$ and $75 \%$ of the market participants who sold at farm gate, local market and urban market, respectively had an access to price information. This implied that the majority of market participants who sold at urban market had an access to price information. Price information aids in acquainting the market participants with the pricing conditions. In terms of group marketing, the results reveal that $7 \%, 35 \%$ and $71 \%$ of the market participants who belong to marketing groups sold their produce at farm gate, local market and urban market, respectively. This implied that the majority of pineapple farmers who marketed their produce at urban market belonged to the group marketing. Marketing in a group enable the farmers to pull their resource together and take advantage of economies of scales in marketing. In term of contract marketing, the results indicate that $64 \%, 53 \%$ and $17 \%$ of the market participants who were under contract marketing sold their produce at farm gate, local market and urban market, respectively. This implied that the majority of those who sold at farm gate were under contract marketing. Marketing under contract guarantees the farmers with the ready market hence; the farmers prefer it to minimize the cost of transportation and that of searching the buyers.

\subsection{Factors Affecting the Choice of Pineapple Marketing Outlets}

Table 4 presents the results of the Multinomial Logit model. Gender, group marketing, pineapple yield, price information, contract marketing, and vehicle ownership significantly influence the choice of pineapple marketing outlets. The Chi-square value of -63.657 showed that likelihood ratio statistics are highly significant $(\mathrm{P}<0.000)$ suggesting that the model had strong explanatory power. The pseudo-R square was 0.4071 indicating the explanatory variable explained about $40.71 \%$ of the variable in the choice of market outlets.

Table 4. Marginal effect from multinomial Logit on the choice of marketing outlets 


\begin{tabular}{lllclcc}
\hline & Farm-gate & & Local market & \multicolumn{2}{c}{ Urban market } \\
Explanatory variable & $\delta \mathrm{y} / \delta \mathrm{x}$ & $\mathrm{P}$-value & $\delta \mathrm{y} / \delta \mathrm{x}$ & $\mathrm{P}$-value & $\delta \mathrm{y} / \delta \mathrm{x}$ & $\mathrm{P}$-value \\
\hline Age & -0.0654 & 0.116 & -0.1656 & 0.184 & -0.0823 & 0.178 \\
Gender & $-0.2649^{*}$ & 0.089 & $0.2781^{*}$ & 0.062 & -0.0133 & 0.886 \\
Education & -0.0088 & 0.679 & -0.0146 & 0.514 & 0.0234 & 0.163 \\
Group marketing & $-0.3873^{* * *}$ & 0.002 & 0.1752 & 0.280 & $0.2121^{*}$ & 0.088 \\
Market experience & -0.0719 & 0.124 & 0.0510 & 0.198 & 0.0144 & 0.354 \\
Pineapple yield & $-0.2973^{* * *}$ & 0.008 & $0.3551^{* * *}$ & 0.002 & 0.0578 & 0.290 \\
Price information & -0.1851 & 0.243 & $0.2973 * *$ & 0.045 & 0.1122 & 0.245 \\
Contract marketing & $0.3154^{*}$ & 0.087 & -0.2872 & 0.108 & -0.0282 & 0.725 \\
Vehicle ownership & 0.0001 & 0.990 & $0.3517^{* *}$ & 0.042 & $0.3616^{* *}$ & 0.021 \\
\hline
\end{tabular}

Number of observations $=100$

Wald chi $^{2}(18): 87.42$

Prob $>\mathrm{Chi}^{2}=0.000$

Pseudo $\mathrm{R}^{2}=0.4071$

Log likelihood $=-63.657324$

Note. ${ }^{* * *}$ : significant at $1 \%$ level; ${ }^{* *}$ : significant at 5\% level; *: significant at $10 \%$ level.

Gender of the household head had a significant influence on the choice of farm-gate and local market. Male-headed household had a higher probability of selling at local market by $27.81 \%$; however, they had a lower probability of selling at farm-gate by $26.49 \%$. A plausible explanation for this is that male-headed households tend to be risk takers thus they are capable of searching markets in distance and competitive places like local market. Conversely, female households head tend to be confined at home by household chores hence hindering them from attending the market places. The finding concurs with that of Morrison et al. (2007), who found that female farmers are faced with gender specific constraints like time burden that limit them from accessing the best market for their output.

Group marketing had a significant influence on the choice of farm-gate and urban market. The farmer who belongs to group marketing had a lower chance of selling at farm gate by $38.73 \%$; but also had a higher chance of selling at urban market by $21.21 \%$. The justification behind this is that the farmers who collectively market their yields to the distance places like urban markets tend to incur a lower transaction costs. Njuki et al. (2009) stated that besides reducing transaction costs, collective marketing empowers farmers to negotiate for better trade terms and prices. This finding is in line with argument of Jari and Fraser (2009), who stated that the farmers who participate in groups have ability to reach a distant market because they are able to share information and broaden social capital within the groups.

Pineapple yield had a significant influence on the choice of farm-gate and local market. An increase in the weight of pineapple yields by one kilogram increases the probability of selling at local market by $35.51 \%$ while a decrease in one kilogram weight of pineapple yields increases the probability of selling pineapple at farm-gate by $29.73 \%$. This means that the farmers who had more yields had more opportunities of selling their produce at the local market places than those with the little produce. The finding is in line with that of Chalwe (2011), who found more of the beans produced being sold to the private traders at the market places than to other households at farm gate.

Price information had a positive influence on the choice of local market. An increase in price information by one unit increases the probability of selling the pineapple yield at local market by $29.73 \%$. Price information informs the farmer on prevailing pricing condition. This shows that the farmers who market their produce at local market incur neither higher transaction cost like urban marketer nor poor prices like farm-gate marketers. 
Contract marketing had a positive significant influence on the choice of farm-gate. The farmers who were under contract in marketing had higher probability of selling at farm-gate by $31.54 \%$. Contract marketing guarantees the farmers with ready market. In essence, a ready market reduces the farmers' costs that are associated with searching the potential buyers and transport. For this reason, the farmers opt to sell at farm-gate in order to incur zero transaction cost. The finding is consistent with that of Escobal and Cavero (2007), who found that marketing of potato at the farm-gate in Peru involves no tax obligation (taxes are not levied) or trade commitments, since the farm is an open market and there is no restriction or barrier.

Vehicle ownership had a significant influence on the choice of local market and urban market. An increase in the vehicle ownership by one vehicle increases the probability of selling at local market and urban market by $35.17 \%$ and $36.16 \%$, respectively. Vehicle ownership helps in reducing the long distance constraints and aids in offering the greater depth in marketing choices. The result concurs with argument of Chalwe (2011) who stated that the availability of on-farm transport increases the probability of transporting goods to private traders in the market.

\section{Conclusion and Recommendation}

The study conclude that gender, group marketing, pineapple yield, price information, contract marketing, and vehicle ownership significantly influence the choice of pineapple marketing outlets. Based on the finding the study recommends that affirmative action should be considered for gender awareness; this is done by empowering more women to engage in pineapple marketing. Group marketing should also be put as priority in marketing to improve the bargaining position of the pineapple farmers as well as a means of lowering transaction costs. Dissemination of price information can be done through mass media, government administration, and extension officer among others. Contract marketing should also be extended to farmers who market their produce at local and urban market.

\section{Acknowledgement}

We are indebted to the African Economic Research Consortium (AERC) for their financial support in the entire research study. Special thanks go to the enumerators for data collection and small scale pineapple farmer who volunteered information.

\section{References}

Barret, C. B. (2008). Smallholder Market Participation: Concepts and Evidence from Eastern and Southern Africa. Journal of Food Policy, 34, 299-317. http://dx.doi.org/10.1016/j.foodpol.2007.10.005

Chalwe, S. (2011). Factors Influencing Bean Producers' Choice of Marketing Channels in Zambia. AMsc. Thesis Presented to the School of Graduate Studies of Zambia University. 
Department for International Development (DFID). (2005). Making Making Systems Work Better for the Poor. Paper presented at ADB-DFID "learning event" ADB Headquarters. Manilla, Filipinas, February 2005.

Escobal, J., \& Cavero, D. (2007). Transaction Cost and Institutional Arrangements in Potato Marketing by Small Producers in Rural Peru. Paper Prepared for the DFID-Funded Research Program, Institutions and Pro-Poor Growth (IPPG), June 2007, Peru. Retrieved from http://www.ippg.org.uk/papers/dp12.pdf

Greene, W. H. (2000). Econometric Analysis (4th edition). Prentice Hall, New Jersey. Retrieved from http://www.abebooks.com/Econometric-Analysis-4th-Edition-William-Greene/4634591 $561 / \mathrm{bd}$

Hazel, P. (2005). Is there a future for small farmers? Agricultural economics, 32(1), 93-10. Retrieved from http://www.bioone.org/doi/full/10.1641/0006-3568

IFAD (International Fund for Agricultural Development). (2001). The challenge of ending rural poverty. Rural Poverty Report. Oxford University Press, Oxford. Retrieved from http://www.ifad.org/poverty/ch.cont.pdf

Jari, B., \& Fraser, C. G. (2009). An Analysis of Institutional and Technical Factors Influencing Agricultural Marketing amongst Smallholder Farmers in the Kat River valley, Eastern Cape, South Africa. African Journal of Agricultural Research, 4, 1129-1137.

Minot, N. (1999). Effect of Transaction Cost on Supply Response and Market Surplus: Simulation using Non-Separable Household Models. MSSD Discussion Paper No. 36. Washington, DC: International food Policy Research Institute.

Minot, N., \& Ngigi, M. (2003). Are Horticultural Exports a Replicable Success Story? Successes in African Agriculture: Building for the Future, IFPRI Paper 7. International Food Policy Research Institute Washington DC. Retrieved from http://www.ifpri.org/sites/default/files/publication/focus 1207.pdf

Montshwe, B. D. (2006). Factors Affecting Participation in Mainstream Cattle Markets by Small-Scale Cattle Farmers in South Africa. MSc. Thesis, University of Free State, Bloemfontein

Morrrison, A., Raju, D., \& Sinha, N. (2007). Gender Equality, Poverty and Economic Growth. The World Bank, Policy Research. Working Paper 4349.

Njuki, J., Kaaria, S, Sanginga, P, Kaganzi, E., \& Magombo, T. (2009). Community Agro Enterprise Development, Experiences from Uganda and Malawi, in Scoones and Thompson.

Reardon, T., \& Timmer, C. P. (2007). Transformation of Markets for Agricultural Output in Developing Countries since 1950: How has Thinking Changed? In R. E. Evenson, \& P. Pingali (Eds.), Handbook of Agricultural Economics (Vol. 3, pp. 2808-2855). 
Agricultural Development: Farmers, Farm Production and Farm Markets. Amsterdam: Elsevier Press.

World Bank. (2008). World Development Report: Agricultural for Development. World Bank, Washington D.C. Retrieved from http://www.ukfg.org/docs/wdr2008.pdf

Zuniga-Arias, G., \& Ruben, R. (2007). Determinants of Market Outlet Choice for Mango Producers in Costa Rica. In R. M. Van Boekel, A. Van Tilburg \& J. Trienekens (Eds.), Tropical Food Chains: Governance Regimes for Quality Management (pp. 49-67). Wageningen Academic Publishers.

\section{Copyright Disclaimer}

Copyright for this article is retained by the author(s), with first publication rights granted to the journal.

This is an open-access article distributed under the terms and conditions of the Creative Commons Attribution license (http://creativecommons.org/licenses/by/3.0/). 